\title{
Understanding guests' intention to visit green hotels
}

\section{Abstract}

The purpose of this study was to expand existing knowledge of hotel consumers' green behaviours by merging value-belief-norm theory and the theory of planned behaviour into one theoretical framework to understand comprehensively consumers' decision-making processes with respect to their intentions to visit a green hotel. Data collected from 757 respondents were analysed. The results indicate that our integrated framework demonstrates a favorable level of prediction power for guests' behavior, which verified the superiority of the suggested framework. Furthermore, its findings from fuzzy-set qualitative comparative analysis (fsQCA) indicate that: (1) attitude toward green hotels, perceived behavioural control, sense of obligation, and corporate image are key drivers of guests' intentions to visit green hotels; (2) three distinct configurations of guests' intention drivers are likely to result in a high degree of intentions among customers to visit green hotels. The three solutions all contain the conditions of high attitude, corporate image, biospheric value, and green activities, which means that these conditions are vital components of a high intention among customers to visit green hotels. This study contributes to the growing literature on sustainability in marketing and practice by providing useful insights about the determinants of guests' behaviour to use green hotels in the Egyptian hospitality context. It is one of the first empirical studies examining factors affecting guests' behavior to use green hotels in the Egyptian hospitality context.

Keywords: Green hotels, Theory of planned behavior, Value-belief-norm theory, Corporate Image, Structural Equation Modelling, and fsQCA. 


\section{Introduction}

The phenomenon of green customer behavior has emerged as a new paradigm of marketing for researchers and marketers in the realm of customer behavior studies (Lai \& Cheng, 2016). In this regard, previous research has paid considerable attention to the term "green" in the hospitality and tourism sector (Han, Meng, \& Kim., 2017; Morren \& Grinstein, 2016). Any hotel seeks to improve consumers' behavior vis-à-vis its business (Jani \& Han, 2013). Several hotels have developed sustainability programs, guidelines, and plans with a view to improving their consumers' positive behavior or intentions (Han, 2015).

Over the last few decades, a remarkable awareness of sustainable consumption has grown among consumers and businesses (Paul, Modi, \& Patel., 2016; Tang \& Lam, 2017), as consumers become more aware of the seriousness of environmental issues and continuously search for and use green products and services (Lee, Hsu, Han, \& Kim., 2010; Ko, Hwang, \& Kim., 2013; Line \& Hanks, 2016; Suki, 2016; Paul et al., 2016; Yadav, Kumar Dokania, \& Swaroop Pathak., 2016). Similarly, environmental issues represent a major concern for all the firms nowadays that try to reconcile the growth of their business with less harmful effects on natural resources (Yadav et al., 2016). In response to the increase in environmental laws and pressure from society and the market, many amid increasing environmental regulations and societal pressures (Paul et al., 2016). Hotels all over the world have constantly implemented green initiatives and become more familiar with environmental practices (Chan, 2013; Chan, Hon, Chan, \& Okumus., 2014).

The concept of a green hotel is well articulated by the Green Hotels Association (2008), which states that "Green Hotels are environmentally friendly properties whose managers are eager to institute programs that save water, save energy and reduce solid waste - while saving money - to help protect our one and only earth!" This statement includes key green 
management practices in the hotel industry, such as saving energy and water, managing waste and educating guests about the environment (Kotler, Bowen, \& Makens, 1999). Numerous studies have highlighted the positive outcomes of carrying out green marketing initiatives, especially in the hospitality and tourism industry (Chan, 2013; Han \& Yoon, 2015; Agag, 2019). Ko, Hwang, and Kim (2013) point out that green practices have a significant influence on the corporate image. Kim, Ham, Yang, and Choi (2013) confirm the positive impact of green practices on consumers' intention to visit hotels and hence on the level of hotels' profits (Chan \& Wong, 2006) and their competitive advantage over others (Singjai, Winata, \& Kummer., 2018).

With this in mind, the present study adopts an idiosyncratic distinct approach to investigating the factors that affecting guests' intentions to visit green hotels; it develops and empirically tests a comprehensive framework, and by doing so adds to the current literature since, to the best of our knowledge, this has not so far been done by any other study. The contributions that it makes to the tourism and hospitality literature are: 1) a robust framework which by integrating TPB and VBN theory can provide us with a comprehensive understanding of guests' intention to visit green hotels; 2) a comparison of TPB, VBN, and our suggested framework in order check whether the last of these is superior; 3) an examination of the role of the study variables in guests' intention to visit green hotels; and 4) an answer to the question whether the combination of these variables should be examined, in a better approach, using (fsQCA)?; The findings of this study provide a useful insight into the sources of the intention to visit green hotels. 


\section{Literature Review and Development of Hypotheses}

Our conceptual framework is based on an extended planned behavior theory with a Valuebelief-norm theory (see Fig. 1). The theory of planned behavior (Ajzen, 1991) has been used as a useful model to understand green behavior for various purposes. First, the theory's main factors hold primary predictors of consumers' behavior pertinent in green consumption environment. The effectiveness of TPB in investigating consumers' behaviors has been validated in a great variety of settings (Ajzen, 1991; Lam \& Hsu, 2006; Han et al., 2010; Han, Meng, \& Kim, 2017; Agag \& Eid, 2019). In particular, it has been successfully used in the tourism and hospitality context, for example, in international traveling (Lam \& Hsu, 2004), convention participation (Lee \& Back, 2009), leisure participation (Ajzen \& Driver, 1991), destination choice (Lam \& Hsu, 2006), the online purchase of travel products (Agag \& ElMasry, 2016b), green hotels (Han et al., 2010; Han, 2015). Second, Ajzen (1991) recommended the inclusion of additional variables. It is much appropriated to investigate the relative effect of egoistic and biospheric value and examine customers underlying belief and value structure of green behaviour. Finally, marketers and managers use the planned behaviour theory as a very useful model to develop behavioural change interventions (Roos \& Hahn, 2019). Consequently, the present study model has been developed based on the integration of Ajzen's (1991) theory of planned behaviour with a value-based theory and evaluate its addition based on criteria recommended by Fishbein and Ajzen (2010), addressing the call for further development of this theory (Head \& Noar, 2014).

Furthermore, the present study adopted the VBN theory model in order to enhance the TPB power. Despite the TPB theory has been succeeded in explaining green consumption, it has also faced some criticism by some studies (Hsu, Cai, \& Li., 2010; Gyurko, 2011). One notable criticism of the TPB is its lack of the moral effect consideration. By integrating the TPB theory with the VBN theory, this limitation is supposed to be minimal. Prior studies integrated the 
TPB and VBN for better explanatory power of behaviour (Kiatkawsin \& Han, 2017). Bamberg and Schmidt (2003) asserted that the theories focus on different aspects of social behaviour and were developed in different contexts so they should be integrated due to their differences, not due to their similarities. Ajzen (1991) pointed out that an addition of personal norm could increase the TPB explanatory power, as none of the TPB variables captures the effect of moral considerations, and would consequently bring the moral aspect to the behavioural intention.

Previous research (e.g., Harland, Staats, \& Wilke., 1999; Kiatkawsin \& Han, 2017; Landon, Woosnam, \& Boley, 2018; Park \& Han, 2014) suggests that there are two main domains to predict a consumer's pro environmental behavior. These include self-interest motives and prosocial motives (Han, Lee, \& Hwang, 2016). The former approach is the more traditional view. This approach suggests that consumers are willing to perform a pro-environmental behaviour for personal interest. For example, if a consumer has a favourable attitude toward green product, the consumer is more likely to buy the product. In this aspect, attitudinal theories, such as the theory of planned behaviour (TPB), have been widely applied to predict consumer's pro-environmental behaviour (Han et al., 2016). The latter prosocial motives are explained by the value-belief-norm theory (Stern et al., 1999). The value-belief-norm theory framework has been used in previous studies to examine the role of pro-social motives in consumer's environmentally responsible decision-making (Han, 2014; Landon et al., 2018). For instance, a consumer's sustainable consumption is predominantly affected by their moral consideration. Performing certain types of pro-environmental behaviours often increases one's personal costs (Harland, Staats, \& Wilke., 2007). In other words, consumers may be required to spend more money if they opt for a green item. Moreover, they may need to sacrifice convenience and put more time and effort to find the options available near them.

In early pro-environmental behavior studies, models based on knowledge and attitude towards the environment have been prevalent (Kollmuss \& Agyeman, 2002). This led to many 
public campaigns aiming to increase public knowledge on environmental issues. Later, researchers found this approach to be ineffective (Juvan \& Dolnicar, 2014). Eco-friendly behavior research has been approached via two main avenues, altruism and self-interests (Bamberg \& Moser, 2007). Researchers who view environmentally responsible behaviors to be pro-socially motivated usually adopted moral norm based theories such as the ValueBelieve-Norm (VBN) theory by Stern et al. (1999). On the other hand, there are researchers who view eco-friendly behavior to be motivated by self-interests. Self-interest theories are based on the assumption that actions are motivated by rewards or outcomes (Hsu, Cai, \& Li, 2010). Kiatkawsin and Han (2017) further suggested a mixture of both views is probably the best approach. Therefore, the proposed research model (Fig.1) is anticipated to offer a more comprehensive understanding of guests' behaviour to visit green hotels by integrating TPB and the value-belief-norm theory.

\subsection{Attitude to Green Hotels}

Fishbein and Ajzen (1975, p.15) define attitude as "learned predisposition to respond in a consistently favorable or unfavorable manner with respect to a given object". For the purposes of the present study, attitude refers to the strength of a consumers' favorable or unfavorable feeling towards green hotels. Attitude plays a crucial role in predicting consumers' behavioral intentions (Amaro \& Duarte, 2015; Agag \& El-Masry, 2016c).

Van Liere and Dunlap (1980) speak of the increasing importance of environmental concerns in consumer studies, as customers intend to pay more for ethical and sustainable products (Caruana, 2007). Consequently, Paul et al (2016) propose that environmental concerns as variables must be added to Ajzen's TBP model to more comprehensively understand 
consumers' green purchase intentions, for few studies have explored the effect of environmental concerns on consumers' green purchase intention. Environmental concerns refer to "the degree to which individuals are more aware of the environmental problems as well as supporting all efforts to solve it" (Dunlap \& Jones, 2002, p.485). Furthermore, Hartmann and Apaolaza-Ibáñez (2012) find the positive direct and indirect influence of environmental concerns on consumers' attitudes and their intention to purchase green energy. In the tourism and hospitality context, numerous studies have established that consumers' attitude to green hotels is positively influenced by environmental concerns (Paul et al., 2016).

Because green hotels represent an emerging issue, social influences and positive recognition exert a powerful effect on the sustainable development of green hotels. Wu and Chen (2017) state that consumer behavior is influenced by that of other consumers. Therefore, we should investigate the influence of social motivation on guests' intention to visit green hotels. In the tourism context, several studies have remarked that customers' attitude to green products is positively susceptible to social influence (Kim et al., 2013).

In prior research a high level of awareness of consequence is shown to lead to high social motivation and a more favorable attitude to green hotels (Park \& Ha, 2014). Zhang et al (2017) declare that the awareness of consequences has a positive influence on personal norms and consumers' attitude to green hotels. Moreover, guests with high awareness of the positive consequences of visiting green hotels are more likely to feel under social pressure to visit green hotels. Based on the above discussion, the following hypotheses (null and alternative) are proposed.

Null Hypothesis 1: Environmental concerns have no significant direct and positive influence on guests' attitudes to green hotels.

Alternative Hypothesis 1: Environmental concerns have a direct and positive influence on guests' attitudes to green hotels. 
Null Hypothesis 2: Social motivation has no significant positive influence on guests' attitudes to green hotels.

Alternative Hypothesis 2: Social motivation has a positive influence on guests' attitudes to green hotels.

Null Hypothesis 3: Awareness of consequences has no significant positive influence on guests' attitudes to green hotels.

Alternative Hypothesis 3: Awareness of consequences has a positive influence on guests' attitudes to green hotels.

Null Hypothesis 4: Awareness of consequences has no significant positive influence on perceived behavior control.

Alternative Hypothesis 4: Awareness of consequences has a positive influence on guests' attitudes to green hotels.

Null Hypothesis 5: Awareness of consequences has no significant positive influence on the sense of being obliged to visit green hotels.

Alternative Hypothesis 5: Awareness of consequences has a positive influence on the sense of being obliged to visit green hotels.

\subsection{Values and Beliefs Underlying Green Hotels Visiting Intention}

The VBN theory is a framework built on three components: values, beliefs and norms (Stern et al., 1999). Schwartz (1992, p.21) defined value as "a desirable trans-situational goal varying in importance, which serves as a guiding principle in the life of a person or other social entity". For the value components, Stern et al. (1999) simplified Schwartz's (1992) theory of basic values and implemented it to the VBN. Environmental awareness is generally promoted by the collective values or the altruism value (AV) type. The second type of value, biospheric (BV), refers to the biosphere and other species. Lastly, egoistic value (EV) places an importance on one's own interests within the society (Stern, 2000). Personal values have received major attention from various research disciplines, and their relationships as predictors of personal norm have often been supported (Li \& Cai, 2012; Piscicelli, Cooper, \& Fisher., 2015).

Building on norm activation research by Schwartz (1977, 1994), Stern et al. (1999) argue that personal norms are based on individual values and the motivation to protect them with appropriate behavior. One of the present study objective is to uncover the structure of 
consumers' underlying values and beliefs regarding green consumption. Building on Schwartz's $(1977,1994)$ norm activation and value research, Stern et al. (1999) develop a value-belief-norm theory that suggests an individual's altruistic (i.e., concern for the well-being of other humans) and biospheric (i.e., concern for the state of the environment and the wellbeing of other species) value orientations are positively related to the formation of a personal norm to behave in a sustainable way, while an egoistic value orientation (e.g., material wealth, success, authority) is negatively related to personal norms.

Despite few studies investigated the influence of the value orientation of (egoistic) selfenhancement and (altruistic and bio-spheric) self-transcendence as values on the sense of being obliged to visit green hotels, Roos and Hahn (2019) maintain that consumers' bio-spheric and altruistic value orientation positively influences consumers' personal norms, while consumers' egoistic values negatively affect personal norms. Thus, we propose the following hypotheses:

Null Hypothesis 6: Guests' egoistic values have no significant negative influence on their sense of being obliged to visit green hotels.

Alternative Hypothesis 6: Guests' egoistic values have a negative influence on their sense of being obliged to visit green hotels.

Null Hypothesis 7: Guests' bio-spheric value orientation has no significant positive influence on their sense of being obliged to visit green hotels.

Alternative Hypothesis 7: Guests' bio-spheric value orientation has a positive influence on their sense of being obliged to visit green hotels.

Null Hypothesis 8: Guests' altruistic value orientation has no significant positive influence on their sense of being obliged to visit green hotels.

Alternative Hypothesis 8: Guests' altruistic value orientation has a positive influence on their sense of being obliged to visit green hotels.

\subsection{Corporate Image}

Corporate image as a major determinant for firms' success was a topic of protracted interest among academicians and practitioners in marketing (Yadav et al., 2016), with its essential role in improving customer loyalty and attracting new customers (Zuhri, Malik, \& Haryono, 2018). 
Few studies, however, have explored the link between green marketing initiatives and firm image, although it has been used as a strategic initiative in the hospitality industry (Burchell \& Cook, 2006; Yadav et al., 2016; Eid, El-Kassrawy, \& Agag, 2019 ).

The green initiative represents a major determinant of corporate image because it reflects the firms' concern for the well-being of society and ethical issues, which in turn formulates a better positive image about the firm among consumers (Flavian et al., 2005; Ward \& Lewandowska, 2008; Ko et al., 2013; Elhoushy, Salem, \& Agag, 2019), and at the same time avoids the punishment for neglecting environmental protection (Porter \& Vander Linde, 1995). Thus, most firms try to invest efforts in implementing various CSR activities in order to build and improve their corporate image beyond that of their market competitors (Chang, 2009; Yadav et al., 2016). In the context of tourism, Yadav et al (2016) confirm a positive influence of green activities on corporate image.

\section{Insert Figure 1 about here}

There is no doubt that consumer's use all the available information to formulate their image of the firm that they will deal with; hence, corporate communication is considered one of the major means for firms to maintain and improve their image in the marketplace (Yadav et al., 2016). Information about various green initiatives helps consumer to learn about the value system of the organization (Lee et al., 2010; Wang et al., 2018) which further creates a positive perception about that organization. Davis (1994) stated that organizations have started considering the importance of environmental/green image and have attempted to improve the green image by communicating it by the means of advertising. Further, Pickett, Kangun, and Grove (1995) pointed that green products and services will not be successful at the commercial level until their green attributes are effectively communicated. Most of the companies communicate green advertisements among consumers to build an environmentally responsible 
corporate image (Yadav et al., 2016 ). Communication about CSR activities affects the corporate image held by consumers (Burchell \& Cook, 2006). Thus, information- related social activities exemplifying green initiatives may enhance the positive perception of consumers about the firm. Ko, Hwang, and Kim (2013) find that corporate image is positively influenced by the corporate communication of green practices. Meanwhile, corporate image requires clear and convincing communication from the hotels which in turns enhance their intention to visit green hotels ( Yadav et al., 2016). Moreover, many firms in the area of tourism also pursue certification from a third party to enhance their image (Lee et al., 2010; Geerts, 2014; Martínez, 2015; Yadav et al., 2016; Luo \& Zhang, 2016). Hence, communicating the green initiatives can be an effective way to create a favorable corporate image. Thus, we propose the following hypotheses:

Null Hypothesis 9: Green activities have no significant positive effect on corporate image. Alternative Hypothesis 9: Green activities have a positive effect on corporate image.

Null Hypothesis 10: The corporate communication has no significant positive influence on the corporate image.

Alternative Hypothesis 10: The corporate communication has a positive influence on the corporate image.

Null Hypothesis 11: The green image has no significant positive influence on the corporate image.

Alternative Hypothesis 11: The green image has a positive influence on the corporate image.

\section{4 Green Visit Intention and its Determinants}

Customers' behavioral intentions have gained considerable attention, especially in the hospitality industry and are widely studied in consumer behavior research (Agag \& El-Masry, 2016a; Ponte, Carvajal-Trujillo, \& Escobar-Rodríguez., 2015; Yadav et al., 2016). When a customer has a favorable behavioral intention towards a specific hotel, the probability of his/her 
visiting this hotel and spreading positive WOM will be high in the future, which in turn enhances the hotel's profitability in the long term (Jani \& Han, 2013).

It is suggested that consumers' intentions capture the motivational variables that effect consumer behavior and the greater the consumers' intention to engage in behavior, the more likely should be its performance (Ajzen, 1991). Consumers behavioral intentions have been well studied as a strong determinant of actual behavior (e.g. Davis, Bagozzi, \& Warshaw, 1989; Wu \& Chen, 2017; Ajzen, 2011; Xu et al., 2017). Furthermore, in voluntary contexts, as in the case of environmentally friendly tourism, consumers intention to behave has been postulated as the best predictor of actual behavior (e.g. Han \& Yoon, 2015; Rahman \& Reynolds, 2016; Han \& Hyun, 2017; Kiatkawsin \& Han, 2017; Shin, Im, Jung, \& Severt., 2018; Han et al., 2018; Olya \& Akhshik, 2018).

The theory of planned behavior (TPB) holds that attitude, subjective norms, and perceived behavior control act as determinants of consumer behavioral intention. For the purposes of the present study, attitude refers to the strength of a consumers' favorable or unfavorable feeling towards green products. Attitude plays a crucial role in predicting consumers' behavioral intentions (Amaro \& Duarte, 2015). In the context of green hotels, many studies agree that customers' intention to visit green hotels is positively influenced by their attitude to it (Han \& Yoon, 2015; Line \& Hanks, 2016; Paul et al., 2016; Tang \& Lam, 2017; Paul et al., 2016).

Perceived behavioral control has been postulated as one of the best predictor of consumer behavior or intention (Zhou, Li, \& Liu., 2010). Ajzen (1991, p. 16) defines perceived behavioral control as "the perceived ease or difficulty of performing the behavior" which reflects customers' anticipated obstacles and experiences. Prior studies have seen that perceived behavioral control (PBC) has a positive influence on consumers' intention in various contexts, such as green hotels (Verma \& Chandra, 2018). 
Personal norms or the sense of being obliged, regarding the visiting of green hotels can be defined "as feelings of strong moral obligation to engage in altruistic or green behavior" (Schwartz, 1977, p. 36). Evidence shows that the sense of being obliged to purchase is positively related to green hotels visiting intentions (Jansson, 2011). Prior studies find a positive direct link between the sense of being obliged and consumers' intention to visit green hotels (Prakash \& Pathak., 2017; Jansson, 2011).

Prior studies in marketing and consumer behavior assert the critical role of the corporate image in determining consumers' buying behaviors (Han et al., 2009). Karaosmanoglu and Melewar (2006) describe the corporate image as the aggregation of a set of variables which reflect a firm's identity. In the hospitality context, Han et al (2009) define the corporate image as a customer's overall perceptions of a green hotel, which is shaped on the basis of their previous experience and knowledge regarding this hotel and its features. Ko et al (2013) confirm a positive effect of the corporate image on consumers' purchase intentions. In the context of hospitality and tourism, Lee et al (2010) and Yadav et al (2016) support the strong significant relationship between the corporate image and consumers' purchase intention. Consequently, we may propose the following hypotheses.

Null Hypothesis 12: Guests' attitudes to green hotels has no significant positive influence on their intention to visit green hotels.

Alternative Hypothesis 12: Guests' attitudes to green hotels positively influence their intention to visit green hotels.

Null Hypothesis 13: Perceived behavioral control has no significant positive influence on guests' intention to visit green hotels.

Alternative Hypothesis 13: Perceived behavioral control positively influence guests' intention to visit green hotels.

Null Hypothesis 14: The sense of being obliged has no significant positive influence on guests' intention to visit green hotels.

Alternative Hypothesis 14: The sense of being obliged positively influence guests' intention to visit green hotels. 
Null Hypothesis 15: The corporate image has no significant positive influence on guests' intention to visit green hotels.

Alternative Hypothesis 15: The corporate image positively influence guests' intention to visit green hotels.

Null Hypothesis 16: guests' intention to visit green hotels has no significant positive influence on their actual visiting.

Alternative Hypothesis 16: guests' intention to visit green hotels positively influence their actual visiting.

\section{Methodology}

To test the research null hypotheses, we applied a research approach based on a field survey to collect data from guests who had visited green hotels during the past year through a questionnaire. In the following sections, we discuss the sampling procedures and measures used for the present study.

\subsection{Sampling Procedure}

A positivist research philosophy was adopted with a quantitative approach in order to validate our conceptual framework; the data were collected in September 2018 through a survey questionnaire. A self-administered questionnaire was developed utilizing measures from the prior studies. The study population involved all the customers who had visited green hotels in the past year. In Egypt, tourism policy incorporates green practices as a general objective (Mohamed, Zohry, Mahmoud, \& Elsaied, 2018). El-Gouna town for instance, which is located $22 \mathrm{~km}$ north of Hurghada, was focused on the environment, when it was arranged and constructed. This town was honoured for its dedication toward environment. Green Globe Certification was granted to it for its engineering and ecological responsibility. It draws in vacationers from various nations particularly Germany, UK and Belgium (Ibrahim, 2009). The 
Ministry of Tourism (MoT) focuses on green practices in the hotel business sector. It made something refer to as Green Sharm Initiative which based on the 4 pillars of emissions mitigation, biodiversity, waste management best practices and water conservation. These pillars translate into 33 quantifiable projects to deliver a low carbon, environmental friendly city by the year 2020. It is the primary example in the Middle East that will exchange Sharm El Sheik to be a worldwide green city. It has reduced the gas outflow by $36 \%$, reduced the hotels energy by $13 \%$ for every guestroom, diminished water utilization by $13 \%$ for each current lodging and $28 \%$ for every new hotel, decreased the water wastage by $75 \%$, achieved level 3 out of 5 in the strong waste administration, achieved level 2 out of 3 in sewage treatment, and decreased the coral reef destruction by 5\% every year (OEDC, 2012). In 2017, the hotels sector in Egypt attempted to outfit 100,000 hotel rooms with new clean innovations and solarheated water, which would take 5 years to be installed. Also in 2017, 45 hotels set up a plan to install solar-heated water system framework (Baerbel, 2014). Given that the awareness level of green consumption is low in Egypt consequently, guests were asked to carefully read the description of a green hotels presented in the questionnaire opening.

Following ethical clearance by the human ethics review committee of the University, 4,000 e-mail addresses of prospective participants were bought from a reputable market list company and it also has more than 2.6 million registered travellers (www. directory.esomar.org). The initial e-mails were directed to 4,000 respondents, which randomly chosen utilizing probability sampling methods as e-mail addresses of the travellers have been selected randomly by a generated sampling system. The survey was anonymous, and restricted to consumers aged 18 and above and was approved by the Human Research Ethics Advisory Panel. Two filtering questions put in the beginning of the questionnaire to determine the qualified respondents, which asked the respondent if he/she visited green hotels during the last year as well as the nationality of the target respondent (Are you Egyptian). The respondents who answered the 
questions positively have an access to complete and submit the survey. The e-mail invitation also contains the study purpose, the estimated period to finish the survey filling, and the URL hyperlink of the current study questionnaire. Data collection lasted for approximately two weeks during September 2018. In total, 810 participants were approached and 53 with missing values were excluded (i.e., a 92\% response rate). Therefore, 757 replies were considered valid for further analysis. It should be stressed that the most common rule to determine sample size for PLS estimation consists in determining the sample according to the most complex multiple regression in the model, which consists in either the number of indicators on the most complex formative construct or the largest number of antecedents leading to a construct in the inner model (Hair et al., 2017; (Barclay, Higgins, \& Thompson, 1995). Once determined which is greater, the sample size required is 10 cases per predictor. In the proposed model, the most complex regression involves the number of structural paths directed at the intentions to visit green hotels construct, which are four. Thus, according to this rule, the minimum sample size necessary would be 40 . With 757 responses, the PLS analysis appears to have sufficient power.

Of the 757 respondents who participated in the current study present study, 411 were men $(54.0 \%)$ and 346 were women $(46.0 \%)$. The majority of participants were aged between 30 and $39(42.0 \%)$, had bachelor degree (54.0\%), and had visited green hotels between (3-6) times in the past year $(44.0 \%)$ (see Table 1$)$.

\section{Insert Table 1 about here}

\subsection{Measurement Instruments}

Intention to visit green hotels and actual behavior were measured through four items each borrowed from prior studies (e.g. Ajzen, 1991; Lam \& Hsu, 2006; Lee et al, 2010; Line \& Hanks, 2016 \& Ko et al, 2013). The scales in five items as suggested by Han et al (2011) and Line and Hanks (2016) were adapted to measure the variables of the consumers' attitude 
to green hotels. The four constructs in the model (green image, corporate image, corporate communication, and green activities) were borrowed from Yadav et al (2016), Javalgi et al (1994), Ko et al (2013) and Karaosmanoglu (2006). The construct 'environmental concerns' was measured through four items based on Schuhwerk and Lefkoff-Hagius (1995) and Line and Hanks (2016). Perceived behavior control was operationalized with three items, as proposed by Ajzen (1991), and Ajzen and Fishbein (1980) and Han et al (2010). The sense of being obliged to visit green hotels was measured through three items adopted from De Groot et al (2007) and Onwezen et al (2013). Social motivation was measured using four items adopted from previous studies (e.g. Yu \& Yu, 2010). Altruistic, Bio-spheric, and Egoistic value orientations were adopted from Schwartz (1994) and Stern et al (1999). Finally, awareness of consequences was measured through four items adopted from Ajzen (2006) and Zhang et al (2017).

\section{Data Analysis and Results}

Following Anderson and Gerbing's (1988) recommendation, we used the two-step approach by separating the measurement model from the structural model. First, the psychometric properties (discriminant validity, convergent and reliability,) of the measures used in this research were assessed. Next, structural equation modelling (SEM) was used to examine the hypothesized relationships between the research constructs (Hew et al., 2017).

\subsection{Measurement Model}

To evaluate the measurement model, both reliability and validity must be satisfactory (Hair et al., 2017). All items had significant influence on their specified variables $(\mathrm{p}<0.001)$, and loaded above 0.60 on their constructs (Hair et al., 2017). The findings of the present study provided evidence for each scale unidimensionally (Table 2). The internal consistency of each variable was supported as composite reliability, Cronbachs' $\alpha$ of study constructs gave results 
above 0.70, exceeding the recommended value proposed by Bagozzi and Yi (1988), and Hair et al (2017) (see Table 2). The value of Average Variance Extracted (AVE) for each construct ranged from 0.501 to 0.731 , exceeding the recommended value of 0.50 suggested by Fornell and Larcker (1981), and Hair et al (2017). Therefore, convergent validity was supported. Furthermore, the AVE square root for all variables was always greater than its association with any other variable, which supports the constructs discriminant validity (Klarner et al., 2013) (Table 3).

\section{Insert Tables $2 \& 3$ about here}

This study used Harmans' single-factor test to assess the common method bias. The results indicated that the largest factor accounted for $31.38 \%$ (the variances explained ranged from $19.37 \%$ to $31.38 \%$ ) and no general factor accounted for more than $50 \%$ of the variance (Teo et al,. 2015). Lindell and Whitney's (2001) marker variable method was utilized, using the item "How likely will you talk and share things about green hotels with others". All coefficients remained significant after the marker variable has been controlled. Consequently, the results regarding the common method bias confirm that it was not a serious concern. Furthermore, most of the method factor loadings were insignificant and negative. Consequently, the results regarding the common method bias confirm that it was not a serious concern.

\subsection{Structural model}

As noted above, testing the null hypotheses or the structure model evaluation was taken as the second step in assessing our proposed model after assessing the measurement model. The present study model assigns $51 \%$ to attitude to green products, $27 \%$ to perceived behavioral control, $49 \%$ to sense of being obliged to visit green hotels, $47 \%$ to corporate image, and $72 \%$ to intention to visit green hotels, which indicates that it has a stronger prediction capacity. The results of testing null hypotheses from $\mathrm{H} 1$ to $\mathrm{H} 16$ using PLS-SEM approach are illustrated in 
Figure 2. The values of $\mathrm{APC}=(0.147, \mathrm{p}<0.001), \mathrm{ARS}=(0.629, \mathrm{p}<0.001), \operatorname{AARS}=(0.548, \mathrm{p}$ $<0.001), \mathrm{AVIF}=(2.172)$, and GOF= (0.614) indicate that our model's global fit was suitable

Before testing the proposed links, we compared our model to the VBN model $(\chi 2=720.042$, $\mathrm{df}=174, \mathrm{p}<0.001, \mathrm{APC}=0.276, \mathrm{ARS}=0.417, \mathrm{AARS}=0.385, \mathrm{AVIF}=2.867, \mathrm{GOF}=0.490)$, and TPB model $(\chi 2=229.418, \mathrm{df}=71, \mathrm{p}<0.001, \mathrm{APC}=0.285, \mathrm{ARS}=0.506, \mathrm{AARS}=0.473$, $\mathrm{AVIF}=2.589, \mathrm{GOF}=0.529)$ in order to identify the superiority of the suggested model in assessing the intention to visit green hotels. As demonstrated in Table 4, our suggested framework shows a better fit than did the TPB and the VBN model. Furthermore, our framework demonstrated better predictive ability for guests' intention to visit green hotels (R2 $=0.721)$ than the original VBN $(\mathrm{R} 2=0.583)$, and TPB $(\mathrm{R} 2=0.604)$. A chi-square difference test demonstrated that our proposed model was significantly superior to the VBN theory $(\Delta \chi 2$ $=376.390, \mathrm{p}<.001)$ and TPB $(\Delta \chi 2=869.213, \mathrm{p}<.001)$. The modeling comparisons findings are demonstrated in Table 4.

There are three other significant relationships that have not been proposed in our initial model have been discovered based on the SEM analysis. Those three relationships will be retained in the final model for further discussion. With adding of those three discovered links, our model showed improved fits compared to the hypothesized model and other models e.g. the VBN theory and the TPB model. Fig.2 demonstrated the final model and the results based on the SEM analysis.

All the alternative hypotheses proposed in our study were supported, except H10 and H13 (Table 5). Regarding the value-belief-norm theory, our results revealed that environmental concerns positively influence the attitude to green hotels $(\beta=0.21, \mathrm{p}<0.001)$, which supported alternative H1. Social motivation has a positive effect on the attitude to green hotels $(\beta=0.46$, $\mathrm{p}<0.001$ ), which supported alternative H2. Awareness of consequences has a positive influence on the attitude to green hotels $(\beta=0.32, \mathrm{p}<0.001)$, which supported alternative H3. Awareness 
of consequences has a positive influence on perceived behavioral control $(\beta=0.41, p<0.001)$, which supported H4.

\section{Insert Figure 2 about here}

The sense of being obliged to visit green hotels is influenced by the awareness of consequences, egoistic value orientation, bio-spheric value orientation, and altruistic value orientation $(\beta=0.39,-0.11,0.37,0.21, \mathrm{p}<0.05,0.001$ respectively $)$, which supports alternative H5, H6, H7and H8. Our results indicated a significant association between Green activities, green image and corporate image $(\beta=0.53,0.41, \mathrm{p}<0.001$ respectively), which supports alternative $\mathrm{H} 9$ and alternative $\mathrm{H} 11$, while the corporate communication of green practices has no significant influence on the corporate image, indicating that $\mathrm{H} 10$ is not confirmed. Regarding the TPB, our study indicated that the intention to visit green hotels is influenced by the attitude to green hotels, the sense of being obliged to visit green hotels, and corporate image $(\beta=0.48,0.45,0.27, \mathrm{p}<0.001$ respectively), which supports alternative H12, H14 and H15. However, alternative H13 was not supported: perceived behavioral control was not found to have significant influence on the intention to visit green hotels $(\beta=0.08, p=0.21)$. Furthermore, guests' intentions to visit green hotels has a significant influence on their actual purchase $(\beta=0.79, \mathrm{p}<0.001)$, which supports alternative H16.

\section{Insert Tables 4 \& 5 about here}

\subsection{A Configuration Approach Using Fuzzy-set Qualitative Comparative Analysis (fsQCA)}

Table 3 shows that the values of some of the estimated correlation coefficients are greater than 0.60 . This means that the relationships that have been tested between model variables and intention to visit green hotels may be asymmetric; therefore, the same outcome could be generated by alternative combinations of independent variables (Pappas \& Papatheodorou, 
2017; Woodside, 2013). Although multicollinearity is less than the cut off value 5, it is relatively high, which may cause issues when carrying out multiple regression analysis (Woodside, 2013). Previous studies on green hotels demonstrate a high cause-effect interdependence between factors. FsQCA avoids issues arising from the use of regression analysis (Woodside, 2013). The fsQCA tool responds to the fourth study question in the introduction. Furthermore, previous research had paid considerable attention to fsQCA in various fields, because when it is applied together with SEM, the combination provides a deeper and richer perspective on the data (Mikalef, Pateli, Batenburg, \& Wetering, 2015; Wu, Yeh, \& Woodside, 2014; Woodside, 2014; Leischnig \& Kasper-Brauer, 2015; Pappas et al., 2016). Consequently, this study uses a configuration approach through fsQCA to provide a holistic insight into the drivers of guests' intention to visit green hotels. Thus, fsQCA is judged a suitable complementary tool for investigating the drivers of guests' intention to visit green hotels. The fsQCA approach explores how causal conditions as configurations connect to the outcome of interest by using the set theory approach (Fiss et al., 2013). The fsQCA technique was used to analyze the data in order to explore which conditions lead customers to the outcome of intention to visit green hotels. Applying the fsQCA technique (Ragin \& Davey, 2014) modified the data to fit the extent of membership of cases in sets, with values between 0.0 and 1.0 to alter the conventional factors into fuzzy factors (Ragin et al., 2009).

Two parameters control the choice of solution in fsQCA: raw coverage and consistency. The value of consistency is between 0 and 1 and it indicates a casual condition proportion that the outcome covers. Woodside (2013) pointed out that consistency is comparable to the coefficient of correlation, and shaped a test of the solution's sufficiency. Coverage is thus comparable to the coefficient of determination (R2). A solution or configuration is acceptable if its consistency is greater than $0.75-0.80$, and its coverage is between 0.25 and 0.65 . 
In the present study a combination of TPB and the value-belief-norm theory variables were hypothesized as the causal conditions that affect guests' intention to visit green hotels. The fsQCA technique can reveal how different variables influence guests' intention to visit green hotels. However, it is hard for hotels to pursue a higher level of every driver in order to raise the intention to visit green hotels. Different combinations of these variables should be investigated in order to identify which combinations of them contribute to higher intention among guests to visit green hotels. Therefore, the fsQCA technique was used in an attempt to explore different combinations of the variables that exist among the comparable cases that result in higher intention among guests to visit green hotels.

\subsubsection{Transforming Data into Fuzzy Set}

Ragin (2009) states that the next step in using the fsQCA, technique after constructing the data set is to calibrate the causal conditions (environmental concerns, social motivation, awareness of consequences, egoistic value, biospheric value, altruistic value, green activities, corporate communication, green image, attitude, perceived behavioural control, sense of obligation, and corporate image) and the outcome (guests' intention to visit green hotels). The current study adopts the direct method as the calibration method (Ragin \& Davey, 2014). The study variables were measured on Likert scales; the study used the original values of 1, 3, and 5 as non-membership, cross over point, and full membership respectively.

\subsubsection{Results}

Table 6 shows the fsQCA analysis results for guests' intention to visit green hotels (intermediate solution with guests' intention to visit green hotels). Black cells, "•" indicate the

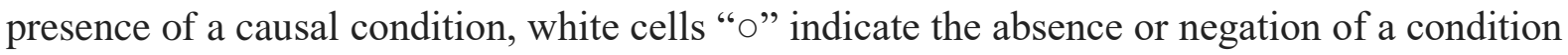
and the blank circles indicate a "doesn't matter" condition. The raw coverage and consistency measures for each solution are included in Table 6. This demonstrates how far guests' intention 
is determined by the identified configurations of environmental concerns, social motivation, awareness of consequences, egoistic value, biospheric value, altruistic value, green activities, corporate communication, green image, attitude, perceived behavioural control, sense of obligation, and corporate image. Based on the results in Table 6, no single variable will strengthen guests' intention to visit green hotels, but combinations of variables will do so. In particular, the results identify three options with high raw consistency (greater than 0.90) as leading to a marked willingness among consumers.

\section{Insert Table 6 about here}

Solution 1 suggests, given its consistency score of 0.962 , that the presence of social motivation, green activities, biospheric value, corporate communication, green image, attitude, perceived behavioural control, sense of obligation, and corporate image and low environmental concerns and awareness of consequences will lead to a marked intentions among consumers to visit green hotels, even in the absence of altruistic value and egoistic value. This configuration is shared by $69 \%$ of the consumers (raw coverage). Alternatively, the consistency score of 0.93 for configuration 2 shows that the presence of attitude, perceived behavioral control, corporate image, social motivation, biospheric value, and green activates, and low awareness of consequences, altruistic value, and green image will result in high intention among guests to visit green hotels even in the absence of sense of obligation, environmental concerns, egoistic value, and corporate communication. This configuration is shared by $54 \%$ of the consumers (raw coverage). Solution 3 had a consistency score of 0.97 , demonstrating that the combination of high attitude, sense of obligation, corporate image, egoistic value, biospheric value, green activities, and green image, and low perceived behavioral control, environmental concerns, awareness of consequences will lead to high intention among consumers to visit green hotels, even in the absence of social motivation, altruistic value, and corporate 
communication. This configuration was shared by $64 \%$ of the consumers (raw coverage). Therefore, the three solutions all contain the conditions of high attitude, corporate image, biospheric value, and green activities, which means that these conditions are vital components of a high intention among customers to visit green hotels.

\section{Discussion and Conclusions}

The present study attempts to investigate the determinants of guests' intentions to visit green hotels in the Egyptian hospitality context. Findings from consumers $(n=757)$ indicated that that our integrated framework demonstrates a favorable level of prediction power for guests' behavior, which verified the superiority of the suggested framework.

The results confirm that environmental concerns, social motivation, and awareness of consequences have a positive effect on the attitude to green hotels. These results are compatible with Line and Hanks (2016), Han (2015), and Wu and Chen (2017), who find that environmental concerns, social motivation, and awareness of consequences positively affect consumers' attitude to green hotels. The results also make it clear that awareness of consequences, egoistic value orientation, altruistic value, and bio-spheric value orientation are relevant antecedents to forming a sense of being obliged to visit green hotels, consistent with previous studies (e.g. Roos \& Hahn, 2019; Klockner, 2013).

Regarding the improvement of corporate image, the results of this study acknowledge that green image and green activities have a significant effect on it. The findings of the present study are in line with Line and Hanks (2016), and Yadav (2016), revealing that green image and green activities have a significant effect on corporate image. Hotels that put an effort into environmental activities can not only avert the punishment attached to disregarding the protection of environment, but also enhance their image. However, it was found that the corporate communication of green practices had no significate influence on the image of a 
green hotel. This can be explained by the current lack of communication from Egyptian hotels to their customers about green practices and initiatives.

Our findings suggest that consumers' intention to visit green hotels is driven by their attitude to green hotels, sense of being obliged, and the corporate image, concurring with the findings of Yadav et al (2016), Han (2015), and Tang and Lam (2017). They conclude that attitude, the sense of being obliged, and corporate image play a significant role in improving consumers' intention to visit green hotels. PBC was not a statistically significant determinant of intentions to visit green hotels. The findings of our study suggest that while our participants felt relatively high perceived behavioral control in visiting green hotels over the normal hotels, this did not lead to intention to visit this green hotel. Underlying this may be an individual's perception that visiting green hotels may not be enough to contribute to greater environmental outcomes. This finding may also be due to a lack of knowledge regarding the implications of green hotels to environmental conditions. In comparison to other green organizational practices including recycling and energy conservation, green hotels seems to be a more elusive concept for consumers.

Our study revealed that behavioral intention fully mediate the effect of attitude on actual behavior but we found that attitude had a direct influence on actual behavior as well. This result means that guests may use green consumption based on the strength of their attitude even when they may not consciously intend to use green consumption. Our results also demonstrated that the explanatory power of the final model enhanced significantly when attitude was explicitly theorized (i.e., $58 \%$ and $76 \%$ of variance in actual behavior explained without and with attitude respectively in the final model). 
The present study contributes to academic knowledge by examining variables influencing guests' intention to visit green hotels in an emerging Middle East context and thus expanding the literature on green marketing. The present study contributes to the previous studies in hospitality context in two ways: first, in order to investigate consumers' decision-making processes with respect to their intentions to visit a green hotel, merging value-belief-norm theory and the theory of planned behaviour into one theoretical framework is efficient in explaining customers' decision formation. The main merit of our conceptual framework is its sufficiency and comprehensiveness. Furthermore, it is widely utilizable for theory and model developments in a variety of green consumption contexts. Moreover, our model, which can be applied in diverse consumption situations relating to green consumption, provides a clear comprehension of consumers' green decision-making process. The theoretical values of the suggested model involving high effectiveness, applicability, and comprehensiveness are noteworthy. The present study fused the VBN with the planned behaviour theory (TPB) and found that our proposed framework more effective in explaining green visiting behaviours.

The value-belief-norm theory has been developed and proposed recently and has yet to gain widespread recognition in wider research contexts. Since the introduction of the value-beliefnorm theory, many researches have validated its constructs in various applications such as exploring conservation behavior (Kaiser, Hubner, \& Bogner, 2005), a cross-national study of pro environmental behavior (Oreg \& Katz-Gerro, 2006) and tourists' intention to behave proenvironmentally in the travel context (Kiatkawsin \& Han, 2017). This research added another research context by successfully demonstrating the application of the model to the guests' intention to visit green hotels. Theoretical implications of this research lie largely on the significant value of the theory's effectiveness in predicting intentions, comprehensiveness in terms of theory deepening and broadening, and its applicability to future researches, leading to the fulfillment of this research's objectives. Kiatkawsin and Han (2017) fused the value-belief- 
norm theory with the expectancy theory and found the proposed model to be significantly more effective in predicting green consumption behaviours. Together with this research, both extended versions of the value-belief-norm theory framework pointed out the possibility of broadening the value-belief-norm theory to apply to a slightly different context.

Second, this study can assist researchers and academicians to further investigate the new variables and process related to green consumption gauge its impact on the corporate image of the hotels. While the significance of corporate image is considered critical in the marketing literature, few studies have tried to examine the influence of green activities on corporate image of the firms and its outcome factor in understanding intention to visit. The present study tries to build an association between components of green marketing (green practices, corporate communication of green practices, green image) and tries to provide a more comprehensive view in understanding the role of the these components of green marketing and corporate image on customer behavior. The marketers should emphasize on proper and effective communication of the green initiatives adopted by the hotels. Considering this aspect, the hotels should communicate their green initiatives through various channels such as print and electronic media and their customer relationship management database. The hotels may also provide information to the guests about their marketing practices and its significance in the betterment of environment. More specifically, in Egyptian context the green practices are at gestation stage, so the consumers will seek more information regarding these practices and an effective communications between hotels and consumers can provide a better result. The hoteliers should promote green campaign emphasizing the importance of environmental issues to the costumers.

Regarding its methodology, the present study explains the merits of integrating traditional approach (SEM) with the fsQCA approach. The SEM approach allows authors to assess the strength of the links between the factors in the conceptual framework, whereas fsQCA yields 
configurations among factors that cause a certain outcome (in this case, intentions to visit green hotels). This research demonstrates the significance of investigating complex causal patterns of drivers, contrarian cases and asymmetric links between drivers and outcomes. The present study contributes by indicating the merits of the fsQCA technique over a regression-based approach to predicting the outcome, demonstrating the suitability of survey data, revealing more recent robustness tests, and demonstrating the socio-demographic profile of the customers in a pathway for intention to visit green hotels to obtain a closer "case orientation". Thus, readers should view the two techniques as complementary.

Our findings have considerable practical implications. The managers of hotels urgently need to understand the key factors that affect guests' green behavior, to help them to formulate efficient programs to encourage guests to visit green hotels. Accordingly, our findings provide some practical implications for managers in the hospitality context.

First, the knowledge of what drives guests' intention to visit green hotels is important for those hotels, who ought to develop actions and strategies aimed at improving consumers' decision-making processes with respect to their intentions to visit a green hotel. The findings of the present study provide hotels managers with the empirical validation of a model that helps them to understand the drivers of guests' intention to visit green hotels. These managers should actively find ways to increase environmental concern (e.g., by promoting green campaigns) that might contribute to building favorable attitudes to green consumption in the long term. As the findings of the present study indicate, hotels' managers can enhance their guests' attitude by communicating with them via all the media to strengthen their belief that they can be more socially committed and can actively participate in protecting the health of the environment if they stay in green hotels. Hotels managers could design and implement environmental education schemes campaigns (courses, conferences and/or talks) directed at the general public in order to increase this environmental knowledge, through deep communal introspection 
regarding the values and ethical conduct that need to be promoted in order to induce changes in individual behavior. Therefore, hotels management strategies should be directed at fostering the public's pro-environmental values and beliefs, in order to differentiate green hotels to match guests' needs and preferences.

Our results also indicate that attitude fully mediates the influence of social motivation and awareness of consequences on consumers' intention. This is why the managers of hotels should enhance the level of guests' attitude in order to maximize the effect of social motivation and awareness of consequences on consumers' intention. Through social media networks, these managers can encourage customers to visit green hotels as an expression of personal responsibility to our environment or can at least advise their relatives to visit green hotels if they cannot themselves afford to do so. Hotels managers should make their green activates visible. For example, Hotel restaurant can have a menu that demonstrate which items are organic grown ingredients, Therefore, these activities will keep their guest in a healthy stay, will help hotels to achieve a competitive advantage and support the influence of guests' attitudes, personal obligations, image, and behavioural control on guests intention to visit green hotels.

Second, For practitioners, boosting the level of image, reputation, and service quality of green hotels to be comparable or even superior to those for non-green hotels is essential to decreasing the attractiveness of alternative non-green hotels. Additionally, in recent years, customers are more and more concerned about their health even when traveling domestically and internationally (Han, 2015; Han \& Hyun, 2017). Offering various health-related advantages to customers during their stay at a green hotels (e.g., organic foods in hotel restaurants, fresh air with natural scent, live potted plants and air cleaners with carbon filters that keeps air healthier in a room, mini bar in a room with green food and beverage options, non-chemical-base amenities, cotton towels and linens, non-toxic environmental cleaning for 
rooms and laundry) (Han et al., 2010) and marketing such health-related benefits to them will help these customers perceive non-green alternatives are less attractive than green hotels. It is also critical that practitioners try to make the green practices of their hotels visible. For instance, a restaurant in a hotel can promotes itself as having menus that describe which items are prepared with organically-grown ingredients. Practitioners may wish to direct their retention strategies and customer attraction toward enhancing customers' awareness of social pressure, environmental problems, and moral obligation to behave in an eco-friendly fashion. For instance, it is crucial for green hotel operators to educate their customers about their green practices as well as the seriousness of environmental problems (e.g., climate change, pollution, and exhaustion of natural resources) and harmful environmental impacts caused by the hotel industry (e.g., excessive use of energy and water, its impact on neighbouring areas, and wastes from rooms, restaurants, and other facilities). These efforts will increase customers' awareness of the negative consequences of environmental problem and enhance perceived level of social pressure for pro-environmental actions, which activate personal norm to take a proenvironmental consumption behavior for a green hotel.

Third, our empirical results support Botsman and Rogers (2011) in their arguments to reflect not only consumers' economic/egoistic motives but also their normative motives to visit green hotels. Foremost, a focus should be on measures to influence the moral obligation of consumers to consume "the right way" and consumers' attitudes toward green hotels. From a strategic perspective, hotels' managers should build on the range of economic/egoistic and normative motives when defining and communicating their mission, vision, and organizational culture to enable green consumers to identify with the hotel. From an operational perspective, managers should emphasize economic (e.g., cost savings) and normative (e.g., efficient use of resources) motives, as well as address consumers' moral obligation when acquiring green consumers through information and advertisement. 
Fourth, guests nowadays are more anxious about their health when traveling internationally and domestically. This being the case, if guests stayed at green hotels, managers could for instance offer them the various health-related benefits that make green hotels more attractive to guests than non-green hotels (e.g. organic foods, non-chemically-based amenities, cotton towels, and fresh air with only natural scents). Communication is very important aspect for the success of eco-friendly products/services (Picket et al., 1995). Considering this aspect, the hotels should communicate their green initiatives through various channels such as print and electronic media and their customer relationship management database. The hotels may also provide information to the guests about their marketing practices and its significance in the betterment of environment. They should also focus on advertising and projecting their green initiatives and may also opt for sponsoring events related to the environment. The proper communication of activities related to social responsibility among consumers leads to information about the organization's value (Sen \& Bhattacharya, 2001; Lee et al., 2009; Yadav et al., 2016) which may help to create a positive image of organization in the consumer's mind. With the help of effective communication of green initiatives the hotels can differentiate with their competitors (Gupta \& Kumar, 2013) and gain competitive advantage. In the Egyptian hospitality context, green practices are at an early stage, thus guests are looking for more information about these green initiatives; hence, effective communication between guests and hotels could enhance the corporate image. Managers could enhance the corporate image of their hotels by implementing green activities and effective communication between the two parties that in turn would improve guests' intention to visit green hotels. Hotels should inform their guests of their green activities, as well as the negative outcomes of using non-green products (e.g. the exhaustion and pollution on natural resources). These efforts and activities will enhance consumers' awareness of the harmful outcomes of using non-green products and will improve guests' positive attitude to green hotels, which will activate their moral obligation 
to buy them. Hotels to make the best use of the awareness of consequences, bio-spheric value orientation, and altruistic values in generating intention to visit green hotels, must improve such mediating factors. The effectiveness on managing these mediator factors will enhance the important role of egoistic value, biospheric value, altruistic value orientation, and consequences awareness in driving guests' intention to visit green hotels. For the government, it is fundamental to build and strengthen the idea of green hotels by awarding and promoting hotels to increase their involvement in protecting the environment. For instance, the government can create more public awareness by including environmental education in the colleges or school's curriculum.

\section{Limitations and Further Research Directions}

Though the present study makes some contributions, it also has some limitations, which provide a direction for future studies. First, our study uses the TPB and VBN models to predict guests' intention to visit green hotels, some variables such as trust in green hotels, their perceived value and self-identity seem to be appropriate elements, which can affect the variables of consumers' visit intentions. Second, the cross-cultural issue was overlooked in our study, so further studies in different countries might add to the knowledge if our proposed model was validated there. Third, our proposed model has been applied in the hospitality context; thus, further studies might focus on other sectors such as fast food restaurants. Last, further studies might conduct longitudinal research because the consumers will reassess the value of green consumption after they experience them. 


\section{References}

Agag, G. (2019). Understanding the determinants of guests' behaviour to use green P2P accommodation. International Journal of Contemporary Hospitality Management.41(3), $31-47$.

Agag, G. \& Eid, R. (2019). Examining the antecedents and consequences of trust in the context of peer-to-peer accommodation. International Journal of Hospitality Management, 81(2),180-192.

Agag, G., \& El-Masry, A. (2016a). Understanding consumer intention to participate in online travel community and effects on consumer intention to purchase travel online and WOM: An integration of innovation diffusion theory and TAM with trust. Journal of Computers in Human Behavior, 60(July), 97-111. 
Agag, G. \& El-Masry, A.A. (2016b). Understanding the determinants of hotel booking intentions and moderating role of habit. International Journal of Hospitality Management, 54(7), 52-67.

Agag, G., \& El-Masry, A. (2016c). Why do consumers trust online travel websites? Drivers and outcomes of consumer trust towards online travel websites. Journal of Travel Research, 55(4), 1-23.

Ajzen, I. (1991). The theory of planned behavior. Organizational behavior and human decision processes, 50(2), 179-211.

Ajzen, I. (2002). Perceived behavioral control, self-efficacy, locus of control, and the theory of planned behavior. Journal of applied social psychology, 32(4), 665-683.

Ajzen .I, Driver, B.L. (1991). Prediction of leisure participation from behavioral, normative, and control beliefs: an application of the theory of planned behavior. Leis Sci 13:185-204

Amaro, S., \& Duarte, P. (2015). An integrative model of consumers intentions to purchase travel online. Tourism Management, 46, 64-79.

Bamberg, S. \& Schmidt, P. (2003). Incentives, morality, or habit? Predicting students' car use for university routes with the models of Ajzen, Schwartz, and Triandis. Environment and behavior, 35(2), 264-285.

Bamberg, S., \& Moser, G. (2007). Twenty years after Hines, Hungerford, and Tomera: A new meta-analysis of psycho-social determinants of pro-environmental behaviour. Journal of Environmental Psychology, 27, 14-25.

Baerbel, E. (2014), Egypt: Green Star Hotels "Download" the Sun [online]. Available from: http://www.solarthermalworld.org/content/egypt-green-star-hotels-download-sun [Accessed 25 November. 2019].

Barclay, D., Higgins, C., \& Thompson, R. (1995). The partial least squares (PLS) approach to causal modeling: personal computer adoption and use as an illustration. Technology Studies, 2(2), 285-309.

Becker-Leifhold, C.V. (2018). The role of values in collaborative fashion consumption-A critical investigation through the lenses of the Theory of Planned Behavior. Journal of Cleaner Production. 22(1), 23-46.

Burchell, J., \& Cook, J. (2006). It's good to talk? Examining attitudes towards corporate social responsibility dialogue and engagement processes. Business Ethics: A European Review, 15(2), 154-170.

Caruana, R. (2007). A Sociological Perspective of Consumer Morality. Journal of Consumer Behaviour, 5(2), 287-304.

Chan, E. S. W. (2013). Managing green marketing: Hong Kong hotel managers' perspective. International Journal of Hospitality Management, 34(1), 442-461.

Chan, E. S. W., \& Wong, S. C. K. (2006). Motivations for ISO 14001 in the hotel industry. Tourism Management, 27(3), 481-492.

Chan, E. S. W., Hon, A. H. Y., Chan, W., \& Okumus, F. (2014). What drives employees' intentions to implement green practices in hotels? The role of knowledge, awareness, concern and ecological behavior. International Journal of Hospitality Management, 40, $20-28$. 
Chan, W. W. (2009). Environmental measures for hotels' environmental management systems. International Journal of Contemporary Hospitality Management, 21(5), 542-560.

Chang, C. P. (2009). The relationships among corporate social responsibility, corporate image and economic performance of high-tech industries in Taiwan. Quality and Quantity, 43(3), 417-429.

Davis, F. D., Bagozzi, R. P., \& Warshaw, P. R. (1989). User acceptance of computer technology: a comparison of two theoretical models. Management Science, 35(8), 9821003.

De Groot, J. I. M., Steg, L., \& Dicke, M. (2007). Morality and reducing car use: testing the norm activation model of prosocial behavior. In F. Columbus (Ed.), Transportation research trends. New York, NY: NOVA Publishers

Dunlap, R., \& Jones, R. (2002). Environmental concern: Conceptual and measurement issues. In Handbook of environmental sociology, ed. R. Dunlap and W. Michelson. London: Greenwood.

Eid, R., El-Kassrawy, Y.A. \& Agag, G. (2019). Integrating destination attributes, political (In) stabIlIty, destination Image, tourist satisfaction, and Intention to recommend: a study of uae. Journal of Hospitality \& Tourism Research, 43(6), 839-866.

Elhoushy, S., Salem, I.E. \& Agag, G. (2019). The impact of perceived benefits and risks on current and desired levels of outsourcing: Hotel managers' perspective. International Journal of Hospitality Management, 35(4),102-419.

Fishbein, M., \& Ajzen, I. (1975). Belief, attitude, intention, and behavior: An introduction to theory and research. Addison-Wesley, Reading, MA.

Fishbein, M., \& Ajzen, I. (2010). Predicting and changing behaviour: The reasoned action approach. New York: Taylor \& Francis.

Fiss, P. C., Sharapov, D., \& Cronqvist, L. (2013). Opposites attract? Opportunities and challenges for integrating large-N QCA and econometric analysis. Political Research Quarterly, 66(1), 191-198.

Geerts, W. (2014). Environmental certification schemes: Hotel managers' views and perceptions. International Journal of Hospitality Management, 39(1), 87-96.

Green Hotels Association. (2008). What are green hotels? Retrieved November 20, 2019, from http://www.greenhotels.com/whatare.htm.

Gyurko, C. C. (2011). A synthesis of Vroom's model with other social theories: An application to nursing education. Nurse Education Today, 31(2), 506-510.

Hair, J. F., Hult, G. T. M., Ringle, C., \& Sarstedt, M. (2017). A primer on partial least squares structural equation modeling (PLS-SEM) (2nd ed.). Thousand Oaks: Sage.

Han, H. (2015). Travelers' pro-environmental behavior in a green lodging context: Converging value-belief-norm theory and the theory of planned behavior. Tourism Management, 47(2), 164-177.

Han, H., Lee, M.J., \& Hwang, J. (2016). Cruise travelers' environmentally responsible decision-making: an integrative framework of goal-directed behavior and norm activation process. Int. J. Hosp. Manage. 53(1), 94-105. 
Han, H., \& Yoon, H. J. (2015). Hotel customers' environmentally responsible behavioral intention: Impact of key constructs on decision in green consumerism. International Journal of Hospitality Management, 45, 22-33.

Han, H., Hsu, L. T. (Jane), \& Lee, J. S. (2009). Empirical investigation of the roles of attitudes to green behaviors, overall image, gender, and age in hotel customers' eco-friendly decision-making process. International Journal of Hospitality Management, 28(4), 519528.

Han, H., Hwang, J., Kim, J., \& Jung, H. (2015). Guests' pro-environmental decision-making process: broadening the norm activation framework in a lodging context. Int. J. Hosp. Manag. 47(2), 96-107.

Han, H., Hsu, L., \& Sheu, C. (2010). Application of the theory of planned behavior to green hotel choice: testing the effect of environmental friendly activities. Tourism Management, $31,325-334$

Han, H. \& Hyun, S. (2017). Fostering customers' pro-environmental behavior at a museum. Journal of Sustainable Tourism, 25(9), 1240-1256.

Han, H., Olya, H.G., Cho, S.B. \& Kim, W. (2018). Understanding museum vacationers' ecofriendly decision-making process: strengthening the VBN framework. Journal of Sustainable Tourism, 26(6), 855-872.

Han, H., Meng, B., \& Kim, W. (2017). Emerging bicycle tourism and the theory of planned behavior. J. Sustain. Tour. 25(2), 292-309.

Harland, P., Staats, H., \& Wilke, H.A. (1999). Explaining pro-environmental intention and behavior by personal norms and the theory of planned behavior. J. Appl. Soc. Psychol. 29 (12), 2505-2528.

Harland, P., Staats, H., \& Wilke, H.A.( 2007). Situational and personality factors as direct or personal norm mediated predictors of pro-environmental behavior: questions derived from norm-activation theory. Basic Appl. Soc. Psychol. 29 (4), 323-334.

Hartmann, P., \& Apaolaza-Ibáñez, V. (2012). Consumer attitude and purchase intention to green energy brands: The roles of psychological benefits and environmental concern. Journal of Business Research, 65(9), 1254-1263.

Head, K. J., \& Noar, S. M. (2014). Facilitating progress in health behaviour theory development and modification: The reasoned action approach as a case study. Health Psychology Review, 8(1), 34-52.

Hew, J. J., Badaruddin, M. N. B. A., \& Moorthy, M. K. (2017). Crafting a smartphone repurchase decision making process: Do brand attachment and gender matter? Telematics and Informatics, 34(4), 34-56.

Hsu, C. H. C., Cai, L. A., \& Li, M. (2010). Expectation, motivation, and attitude: A tourist behavioral model. Journal of Travel Research, 49(3), 282-296.

Ibrahim, Z, (2009), Tourism Development and the Environment on the Egyptian Red Sea Coast, Master Thesis, the University of Waterloo, Canada.

Jani, D., \& Han, H. (2013). Personality, social comparison, consumption emotions, satisfaction, and behavioral intentions. International Journal of Contemporary Hospitality Management, 25(7), 970-993. 
Jansson, J. (2011). Consumer eco-innovation adoption: assessing attitudinal factors and perceived product characteristics. Business Strategy and the Environment, 20(3), 192210.

Juvan, E., \& Dolnicar, S. (2014). The attitude-behaviour gap in sustainable tourism. Annals of Tourism research, 48, 76-95

Kaiser, F. G., Hubner, G., \& Bogner, F. X. (2005). Contrasting the theory of planned behavior with the value-belief-norm model in explaining conservation behavior. Journal of Applied Social Psychology, 35(10), 2150-2170.

Karaosmanoglu, E., \& Melewar, T. C. (2006). Corporate communications, identity and image: A research agenda. Journal of Brand Management, 14(1-2), 196-206.

Kiatkawsin, K. \& Han, H. (2017). Young travellers' intention to behave pro-environmentally: Merging the value-belief-norm theory and the expectancy theory. Tourism Management, 59(2), 76-88.

Kidwell, B., \& Jewell, R. D. (2003). The moderated influence of internal control: An examination across health-related behaviors. Journal of Consumer Psychology, 13(4), 377-386

Kim, E., Ham, S., Yang, I. S., \& Choi, J. G. (2013). The roles of attitude, subjective norm, and perceived behavioral control in the formation of consumers' behavioral intentions to read menu labels in the restaurant industry. International Journal of Hospitality Management, $35,203-213$.

Ko, E., Hwang, Y. K., \& Kim, E. Y. (2013). Green marketing's functions in building corporate image in the retail setting. Journal of Business Research, 66(10), 1709-1715.

Kollmuss, A., \& Agyeman, J. (2002). Mind the gap: Why do people act environmentally and what are the barriers to pro-environmental behavior? Environmental Education Research, $8(3), 239-260$.

Kotler, P., Bowen, J., \& Makens, J. (1999). Marketing for hospitality and tourism (2nd ed). UK: Prentice-Hall

Lam, T., \& Hsu, C. H. C. (2006). Predicting behavioral intention of choosing a travel destination. Tourism Management, 27(1), 589-599.

Lai,C.K., \& Cheng, E.W. (2016). Green purchase behavior of undergraduate students in Hong Kong. Soc. Sci. J. 53 (1), 67-76.

Landon, A.C., Woosnam, K.M. \& Boley, B.B. (2018). Modeling the psychological antecedents to tourists' pro-sustainable behaviors: an application of the value-belief-norm model. Journal of Sustainable Tourism, 26(6).1-16.

Lee, J. S., Hsu, L. T., Han, H., \& Kim, Y. (2010). Understanding how consumers view green hotels: How a hotels' green image can influence behavioural intentions. Journal of Sustainable Tourism, 18(7), 901-914.

Leischnig, A., \& Kasper-Brauer, K. (2015). Employee adaptive behavior in service enactments. Journal of Business Research, 68(2), 273-280.

Line, N. D., \& Hanks, L. (2016). The effects of environmental and luxury beliefs on intention to patronize green hotels: the moderating effect of destination image. Journal of 
Sustainable Tourism, 24(6), 904-925.

Li, M., \& Cai, L. A. (2012). The effect of personal values on travel motivation and behavioral intention. Journal of Travel Research, 51(4), 473-487.

Martínez, P. (2015). Customer loyalty: exploring its antecedents from a green marketing perspective. International Journal of Contemporary Hospitality Management, 27(5), 896917.

Mikalef, P., Pateli, A., Batenburg, R. S., \& Wetering, R. V. D. (2015). Purchasing alignment under multiple contingencies: a configuration theory approach. Industrial Management \& Data Systems, 115(4), 625-645.

Miao, L., \& Wei, W. (2016). Consumers' pro-environmental behavior and its determinants in the lodging segment. Journal of Hospitality and Tourism Research, 40(3), 319-338.

Mohamed, A., Zohry, M., Mahmoud, M. \& Elsaied, M. (2018). Green Practices in Quick Service Restaurants in Egypt (Analytical Study). International Journal of Heritage, Tourism and Hospitality, 12 (3 (Special Issue)), 133-144.

Morren, M., \& Grinstein, A. (2016). Explaining environmental behavior across borders: A meta-analysis. Journal of Environmental Psychology, 47, 91-106. https://doi.org/10.1016/j.jenvp.2016.05.003

Morsing, M., \& Schultz, M. (2006). Corporate social responsibility communication: stakeholder information, response and involvement strategies. Business Ethics: A European Review, 15(4), 323-338.

OECD - Organization for Economic Co-operation and Development (2012), OECD Tourism Papers Green Innovation in Tourism Services, Vienna: OECD Publishing.

Olya, H.G. \& Akhshik, A. (2018). Tackling the Complexity of the Pro-environmental Behavior Intentions of Visitors to Turtle Sites. Journal of Travel Research, p.0047287517751676.

Oreg, S., \& Katz-Gerro, T. (2006). Predicting proenvironmental behavior crossnationally: Values, the theory of planned behavior, and value-belief-norm theory. Environmental and Behavior, 38(4), 462-483

Park, J., Han, S. (2014). Understanding consumer recycling behavior: combining the theory of planned behavior and the norm activation model. Fam. Consum. Sci. Res. J. 42(3), 278291.

Pappas, N., \& Papatheodorou, A. (2017). Tourism and the refugee crisis in Greece: Perceptions and decision-making of accommodation providers. Tourism Management, 63, 31-41.

Paul, J., Modi, A. \& Patel, J. (2016). Predicting green product consumption using theory of planned behavior and reasoned action. Journal of retailing and consumer services, 29(2), 123-134.

Pickett, G.M., Kangun, N. \& Grove, S.J. (1995). An examination of the conserving consumers: implications for public policy formation on promoting conservation behavior, in Polonsky, M. J., and Mintu-Wimsatt, A. T. (Eds.), Environmental Marketing: Strategies, Practice, Theory and Research, The Haworth Press: New York, pp. 77-99. 
Piscicelli, L., Cooper, T., \& Fisher, T. (2015). The role of values in collaborative consumption: Insights from a product-service system for lending and borrowing in the UK. Journal of Cleaner Production, 97, 21-29.

Ponte, E.B., Carvajal-Trujillo, E. \& Escobar-Rodríguez, T. (2015), "Influence of trust and perceived value on the intention to purchase travel online: integrating the effects of assurance on trust antecedents", Tourism Management, 47(3), 286-302.

Porter, M.E. \& Vander Linde, C. (1995). Green and competitive: ending the stalemate. Harvard business review, 73(5), 120-134.

Prakash, G., Pathak, P. (2017). Intention to buy eco-friendly packaged products among young consumers of India: a study on a developing nation. J. Clean. Prod. 141(1), 385-393.

Rahman, I., \& Reynolds, D. (2016). Predicting green hotel behavioral intentions using a theory of environmental commitment and sacrifice for the environment. International Journal of Hospitality Management, 52, 107-116.

Roos, D. and Hahn, R. (2017). Understanding Collaborative Consumption: An Extension of the Theory of Planned Behavior with Value-Based Personal Norms. Journal of Business Ethics, 2(1).1-19.

Schuhwerk, M. E., \& Lefkoff-Hagius, R. (1995). Green or non-green? Does type of appeal matter when advertising a green product? Journal of Advertising, 24(2), 45-54.

Schwartz, S. H. (1992). Universals in the content and structure of values: Theoretical advances and empirical tests in 20 countries. In M. P. Zanna (Ed.), Advances in experimental social psychology (Vol. 25, pp. 1-65). Orlando, FL: Academic Press.

Schwartz, S. H. (1977). Normative influences on altruism. In L. Berkowitz (Ed.), Advances in experimental social psychology (Vol. 10, pp. 221e279). New York, NY: Academic Press

Shin, Y.H., Im, J., Jung, S.E. and Severt, K. (2018). The theory of planned behavior and the norm activation model approach to consumer behavior regarding organic menus. International Journal of Hospitality Management, 69(1), 21-29.

Singjai, K., Winata, L. \& Kummer, T.F. (2018). Green initiatives and their competitive advantage for the hotel industry in developing countries. International Journal of Hospitality Management, 75, 131-143.

Stern, P. C., Dietz, T., Abel, T., Guagnano, G. A., \& Kalof, L. (1999). A value-belief-norm theory of support for social movements: the case of environmentalism. Research in Human Ecology, 6(2), 81-97

Stern, P.C., \& Dietz, T. (1994). The value basis of environmental concern. Journal of Social Issues, 50(3), 65-84.

Tang, C. M. F., \& Lam, D. (2017). The role of extraversion and agreeableness traits on Gen Ys' attitudes and willingness to pay for green hotels. International Journal of Contemporary Hospitality Management, 29(1), 607-623.

Teo, A. C., Tan, G. W. H., Ooi, K. B., Hew, T. S., \& Yew, K. T. (2015). The effects of convenience and speed in m-payment. Industrial Management \& Data Systems, 115(2), 311-331.

Verma, V.K. \& Chandra, B. (2018). An application of theory of planned behavior to predict 
young Indian consumers' green hotel visit intention. Journal of Cleaner Production, 172(3),1152-1162.

Wang, J., Wang, S., Wang, Y., Li, J. \& Zhao, D. (2018). Extending the theory of planned behavior to understand consumers' intentions to visit green hotels in the Chinese context. International Journal of Contemporary Hospitality Management. 23(4), 114-127.

Woodside, A. G. (2013). Moving beyond multiple regression analysis to algorithms: Calling for adoption of a paradigm shift from symmetric to asymmetric thinking in data analysis and crafting theory. Journal of Business Research, 66(4), 463-472.

Woodside, A. G. (2014). Embrace perform model: Complexity theory, contrarian case analysis, and multiple realities. Journal of Business Research, 67(12), 2495-2503.

World Business Council for Sustainable Development (WBCSD). (2016). Sustainable consumption - Facts and trends. Geneva: Author

Wu, B. \& Chen, X. (2017). Continuance intention to use MOOCs: Integrating the technology acceptance model (TAM) and task technology fit (TTF) model. Computers in Human Behavior, 67(1), 221-232.

Wu, P. L., Yeh, S. S., \& Woodside, A. G. (2014). Applying complexity theory to deepen service dominant logic: Configural analysis of customer experience-and-outcome assessments of professional services for personal transformations. Journal of Business Research, 67(8), 1647-1670.

Xu, X., Li, Q., Peng, L., Hsia, T.L., Huang, C.J. \& Wu, J.H. (2017). The impact of informational incentives and social influence on consumer behavior during Alibaba's online shopping carnival. Computers in Human Behavior, 76(1), 245-254.

Yadav,R., \& Pathak,G.S.(2016).Young consumers' intention towards buying green products in a developing nation: extending the theory of planned behavior. J.Clean.Prod.135(3), 732739.

Yadav, R., Kumar Dokania, A., \& Swaroop Pathak, G. (2016). The influence of green marketing functions in building corporate image. International Journal of Contemporary Hospitality Management, 28(10), 2178-2196.

Yu, T. K., \& Yu, T. Y. (2010). Modelling the factors that affect individuals' utilisation of online learning systems: An empirical study combining the task technology fit model with the theory of planned behavior. British Journal of Educational Technology, 41(6), 1003-1017.

Zhang, X., Geng, G. \& Sun, P. (2017). Determinants and implications of citizens' environmental complaint in China: Integrating theory of planned behavior and norm activation model. Journal of Cleaner Production, 166(3), 148-156.

Zhou, T., Li, H., \& Liu, Y. (2010). The effect of flow experience on mobile SNS users' loyalty. Industrial Management \& Data Systems, 110(6), 930-946.

Zuhri, M., Malik, D. \& Haryono, A.T (2018). Effect of service, price and company image on consumer loyalty with consumer satisfaction as mediation (study at workshop of nasmoco majapahit semarang). Journal of Management, 4(4). 278-310. 